\title{
Sediment production and soil water infiltration under different simulated rainfall characteristics
}

\author{
Wilk S. de Almeida ${ }^{1}$, Daniel F. de Carvalho² ${ }^{2}$ Fernandes A. C. Pereira ${ }^{3}$ \& Janaína R. C. Rouws ${ }^{4}$ \\ ${ }^{1}$ Instituto Federal de Educação, Ciência e Tecnologia de Rondônia. Colorado do Oeste, RO, Brasil. E-mail: wilk.almeida@ifro.edu.br - ORCID: \\ 0000-0001-5872-9484. \\ ${ }^{2}$ Universidade Federal Rural do Rio de Janeiro/Instituto de Tecnologia/Departamento de Engenharia. Seropédica, RJ, Brasil. E-mail: \\ daniel.fonseca.carvalho@gmail.com (Corresponding author) - ORCID: 0000-0001-7629-9465 \\ ${ }^{3}$ Universidade Federal de Lavras/Departamento de Ciência do Solo. Lavras, MG, Brasil. E-mail: fernandes.inp@gmail.com - ORCID: 0000- \\ 0001-6257-8949 \\ ${ }^{4}$ Empresa Brasileira de Pesquisa Agropecuária/Embrapa Agrobiologia. Seropédica, RJ, Brasil. E-mail: janaina.rouws@embrapa.br - ORCID: 0000-0003- \\ 1816-3505
}

\begin{abstract}
The study was carried out to evaluate sediment production, water infiltration and surface runoff in an Ultisol under simulated rainfalls with similar erosivity, but different combinations of intensity (Int) and duration (Dur). The rainfalls were applied after soil tillage in the period from August to September 2017, in Seropédica, RJ State, Brazil. Using a computer program, the treatments were defined from the erosivity calculated for a rainfall with intensity of $60 \mathrm{~mm} \mathrm{~h}^{-1}$ and duration of $60 \mathrm{~min}$, resulting in the other combinations of Int and Dur: $44.5 \mathrm{~mm} \mathrm{~h}^{-1}$ and $106 \mathrm{~min} ; 53.5 \mathrm{~mm} \mathrm{~h}^{-1}$ and $78 \mathrm{~min} ; 66.9 \mathrm{~mm} \mathrm{~h}^{-1}$ and $48 \mathrm{~min}$; and $76.5 \mathrm{~mm} \mathrm{~h}^{-1}$ and $38 \mathrm{~min}$, in a completely randomized design with five repetitions. Sediment production varied from 2.17 to $6.11 \mathrm{~g} \mathrm{~m}^{-2}$, respectively, in the treatments with Int $53.5 \mathrm{~mm} \mathrm{~h}^{-1}$ and Dur $78 \mathrm{~min}$ and Int $44.5 \mathrm{~mm} \mathrm{~h}^{-1}$ and Dur 106 min. Stable infiltration rate $\left(\mathrm{mm} \mathrm{h}^{-1}\right)$ were $21.6,37.7,31.4,29.5$, and 22.4 , respectively, in the treatments Int $44.5 \mathrm{~mm} \mathrm{~h}^{-1}$ and Dur $106 \mathrm{~min}$; Int $53.5 \mathrm{~mm} \mathrm{~h}^{-1}$ and Dur $78 \mathrm{~min}$; Int $60.4 \mathrm{~mm} \mathrm{~h}^{-1}$ and Dur $60 \mathrm{~min}$; Int $66.9 \mathrm{~mm} \mathrm{~h}^{-1}$ and Dur $48 \mathrm{~min}$; and Int $76.5 \mathrm{~mm} \mathrm{~h}^{-1}$ and Dur $38 \mathrm{~min}$. The different combinations of intensity and duration of rainfalls with similar erosivity change sediment production, but do not significantly influence surface runoff and water infiltration in the soil.
\end{abstract}

Key words: erosivity, rainfall intensity, rainfall duration, surface runoff

\section{Produção de sedimentos e infiltração de água no solo sob diferentes características de chuva simulada}

RESUMO: O estudo foi realizado com objetivo de avaliar a produção de sedimentos, a infiltração da água e o escoamento superficial em um Argissolo Vermelho-Amarelo sob chuvas simuladas com erosividades semelhantes, mas com distintas combinações de intensidade de precipitação (Int) e duração (Dur). As chuvas foram aplicadas após o preparo do solo e no período de agosto a setembro de 2017 em Seropédica, RJ, Brasil. Utilizando um programa computacional, os tratamentos foram definidos a partir do cálculo da erosividade para uma chuva de $60 \mathrm{~mm} \mathrm{~h}^{-1}$ e $60 \mathrm{~min}$ de duração, resultando nas demais combinações de Int e Dur: 44,5 $\mathrm{mm} \mathrm{h}^{-1}$ e $106 \mathrm{~min} ; 53,5 \mathrm{~mm} \mathrm{~h}^{-1}$ e $78 \mathrm{~min} ; 66,9 \mathrm{~mm} \mathrm{~h}^{-1}$ e $48 \mathrm{~min}$; e $76,5 \mathrm{~mm} \mathrm{~h}^{-1}$ e $38 \mathrm{~min}$, em delineamento inteiramente casualizado com cinco repetições. A produção de sedimentos variou de 2,17 a $6,11 \mathrm{~g} \mathrm{~m}^{-2}$, respectivamente, nos tratamentos com Int 53,5 $\mathrm{mm} \mathrm{h}^{-1}$ e Dur 78 min e Int 44,5 $\mathrm{mm} \mathrm{h}^{-1} \mathrm{e} \mathrm{Dur}$ $106 \mathrm{~min}$. As taxas de infiltração estáveis $\left(\mathrm{mm} \mathrm{h}^{-1}\right)$ foram de 21,$6 ; 37,7 ; 31,4 ; 29,5 ;$ e 22,4, respectivamente, nos tratamentos Int 44,5 $\mathrm{mm} \mathrm{h}^{-1}$ e Dur $106 \mathrm{~min}$; Int 53,5 $\mathrm{mm} \mathrm{h}^{-1}$ e Dur $78 \mathrm{~min}$; Int 60,4 $\mathrm{mm} \mathrm{h}^{-1}$ e Dur $60 \mathrm{~min}$; Int $66,9 \mathrm{~mm} \mathrm{~h}^{-1}$ e Dur $48 \mathrm{~min}$; e Int 76,5 $\mathrm{mm} \mathrm{h}^{-1}$ e Dur $38 \mathrm{~min}$. As diferentes combinações de intensidade de precipitação e duração das chuvas com erosividade semelhante alteram a produção de sedimentos, mas não influenciam significativamente o escoamento superficial e a infiltração da água no solo.

Palavras-chave: erosividade, intensidade de precipitação, duração da chuva, escoamento superficial 


\section{INTRODUCTION}

Human activity and land use-related changes are the main causes of accelerated soil erosion, which alters the cycle of nutrients and carbon and the global socioeconomic conditions (Borrelli et al., 2013; Wang et al., 2016). Although water erosion is identified as the most serious cause of soil degradation in the world (Wang et al., 2017; Wu et al., 2018a), the global patterns of rainfall erosivity remain poorly quantified and their estimates have high uncertainties (Panagos et al., 2017).

Rainfall characteristics, such as intensity, duration, kinetic energy and erosivity, have been studied, and currently the focus continues on the mechanistic research about soil erosion (Wang et al., 2017). Among the characteristics of the rainfall, the intensity and duration are the dominant factors controlling the hydrological response and interill erosion (Kinnell, 2012; Ran et al., 2012; Bako et al., 2016; Wang et al., 2017; Wu et al., 2018b).

Although the erosive process changes according to the rainfall occurrence pattern (Ran et al., 2012; An et al., 2014; Wang et al., 2017; Zhang \& Wang, 2017; Wu et al., 2018b), no research results were found quantifying the effect of the combination of duration and intensity of simulated rainfalls with equal erosivity on the process of sediment production and on soil water infiltration under field conditions.

To understand the effect of the type of rainfall on sediment production and soil water infiltration, this study considered the hypothesis that the physical characteristics of rainfalls with equal erosivity alter the erosive process and soil water infiltration; consequently, the main objective was to quantify the effect of the association between duration and intensity of simulated rainfalls with similar erosivity on surface runoff, sediment production and water infiltration in Ultisol.

\section{Material ANd Methods}

The experiment was conducted from August to September 2017 in the Experimental Field of Embrapa Agrobiologia, located in the municipality of Seropédica, RJ State, Brazil $\left(22^{\circ}\right.$ $46^{\prime} 23^{\prime \prime} \mathrm{S}, 43^{\circ} 41^{\prime} 49^{\prime \prime} \mathrm{W}$ and altitude of $33 \mathrm{~m}$ ). The regional climate is Aw according to Köppen's climatic classification, with annual averages of rainfall and temperature varying from 1,300 to $1,600 \mathrm{~mm}$ and from 22 to $24{ }^{\circ} \mathrm{C}$, respectively (Alvares et al., 2013). The soil of the experimental area, classified as Ultisol (Santos et al., 2018), has medium texture, with 540, 150 and $310 \mathrm{~g} \mathrm{~kg}^{-1}$ of sand, silt and clay, respectively, in the $0-27 \mathrm{~cm}$ layer (Cruz, 2006). The topography of the experimental area is undulating, with an average slope of $9 \%$. The area had been under fallow since 2012 and its surface remained covered with Paspalum notatum. For the present study, the soil layer from 0 to $20 \mathrm{~cm}$ was tilled with two operations with a disc harrow and one with a leveling harrow.

The methodology of Wischmeier \& Smith (1958) was used to calculate the erosivity index $\left(871.266 \mathrm{MJ} \mathrm{mm} \mathrm{ha}^{-1} \mathrm{~h}^{-1}\right)$ for the rainfall with intensity (Int) of $60 \mathrm{~mm} \mathrm{~h}^{-1}$ and duration (Dur) of $60 \mathrm{~min}$, which has been used in numerous research studies (Almeida et al., 2016, 2018; Carvalho et al., 2015) and served as reference to define the treatments. From the value of erosivity and using the computer program Energia (Alves Sobrinho et al., 2001), Int and Dur were varied in such a way to provide similar values of erosivity, maintaining the other variables of the program, which are related to the characteristics of the rainfall simulator: falling height of raindrops $(2.3 \mathrm{~m})$, pumping pressure $(34.0 \mathrm{kPa})$ and mean raindrop diameter $(2.0 \mathrm{~mm})$. Thus, the following treatments were established: Int $44.5 \mathrm{~mm} \mathrm{~h}^{-1}$ and Dur $106 \mathrm{~min}$; Int $53.5 \mathrm{~mm} \mathrm{~h}^{-1}$ and Dur $78 \mathrm{~min}$; Int $60.0 \mathrm{~mm} \mathrm{~h}^{-1}$ and Dur $60 \mathrm{~min}$; Int $66.9 \mathrm{~mm} \mathrm{~h}^{-1}$ and Dur $48 \mathrm{~min}$; and Int $76.5 \mathrm{~mm} \mathrm{~h}^{-1}$ and Dur $38 \mathrm{~min}$. The experimental design used was completely randomized, with five treatments and five repetitions.

The simulated rainfalls were applied using a rotating-disk rainfall simulator developed by Alves Sobrinho et al. (2008), which operates with two parallel Veejet 80.150 nozzles and has been used in studies on erosion (Carvalho et al., 2015; Almeida et al., 2016) and on soil water infiltration (Almeida et al., 2018). The experimental plots had a useful area of $0.7 \mathrm{~m}^{2}$ and were delimited by galvanized steel plates, with a funnel-like structure on one side, which allowed the water volume drained on surface to be collected. The steel plates were buried into the soil up to $0.15 \mathrm{~m}$ deep.

Before each rainfall application, soil water content was standardized in the treatments by pre-wetting the plots. Once the rainfall application started, the time required for surface runoff to begin was quantified and, from this moment, rainfall duration was that pre-established for each treatment. After the surface runoff began, the drained water volume was measured every minute and, every five minutes, a sample was collected to estimate sediment production. In the laboratory, aluminum sulfate was added to the samples to promote flocculation and precipitation of suspended solids for $24 \mathrm{~h}$. After this period, the water excess of each sample was removed and the solid material was placed in an oven at $105{ }^{\circ} \mathrm{C}$. After drying, the sediment mass was calculated in each test based on the sum of samples from the same rainfall.

Soil water infiltration was quantified using the water volumes measured every minute in the collecting gutter, after the beginning of surface runoff. Then, the infiltrated water depth was calculated by difference between the depth applied by the simulator and the surface runoff depth (SRD), which was calculated by the relationship between the water volume drained and the experimental plot area. Subsequently, soil water infiltration rate was determined by the relationship between the infiltrated water depth and the considered interval of collection.

To quantify the soil water content (moisture) prior to the rainfalls, disturbed samples were collected using a screw auger for $0-0.10 \mathrm{~m}$ depth, beside the plots, before the beginning of rainfall application. At the same depth and within the plots, after rainfall application, samples were collected to quantify organic carbon content and wet aggregate stability (mean weight diameter - MWD, mean geometric diameter - MGD) and undisturbed samples $\left(100 \mathrm{~cm}^{3}\right)$ were collected to estimate soil bulk density and porosity (macro, micro and total). The methodologies described in Teixeira et al. (2017) were used in the laboratory analyses.

Residual normality was verified by the Shapiro-Wilk test (Shapiro \& Wilk, 1965) and residual homogeneity by Bartlett's 
test (Bartlett, 1937). There was no need to transform the data in order to meet the assumptions for analysis of variance. Thus, the effect of treatments was evaluated through analysis of variance ( $F$ test, $p \leq 0.05$ ). When there was a significant difference between treatments, the means were compared by Scott-Knott test, at $\mathrm{p} \leq 0.05$. Data statistical analysis was performed using the R software.

\section{Results AND Discussion}

The organic carbon content and physical attributes of the soil were similar among treatments at the evaluated depth $(0-0.10 \mathrm{~m})$ (Table 1$)$. The uniformity of the experimental area is related to the fallow period, to the effect of the root system of the grass present in the area, which brings carbon to the soil and favors its aggregation and water infiltration, to its organic carbon content and to its overturning. Regarding soil moisture, significant differences were found between treatments, which can be justified by the period of the field experiment. The moisture content prior to the tests was similar in the plots of the same treatment, in which the rainfalls were applied almost always on the same day of test. However, precipitation occurred between the rainfall applications in the different treatments, in some situations, making it impossible for the antecedent moisture to remain the same in the entire experimental area.

The highest cumulative surface runoff depths occurred for rainfalls with Int 44.5 and Dur 106 min and with Int $76.5 \mathrm{~mm} \mathrm{~h}^{-1}$ and Dur $38 \mathrm{~min}$ (Figure 1A). The average increment in surface runoff from the lowest to the highest surface runoff depth was $46 \%$ and for the other rainfalls, the values were similar. The lowest and highest cumulative averages of surface runoff were 17.1 and $30.53 \mathrm{~mm}$, respectively, in the rainfalls with Int $53.5 \mathrm{~mm} \mathrm{~h}^{-1}$ and Dur $78 \mathrm{~min}$ and Int $76.5 \mathrm{~mm} \mathrm{~h}^{-1}$ and Dur $38 \mathrm{~min}$. Considering the same duration, it can be noted that the highest depths drained were found with the highest intensities, except in the treatment with Int 53.5 and Dur $78 \mathrm{~min}$, probably due to the lower average soil moisture in this plot, which favored water infiltration in the soil.

The treatment with the rainfall of highest intensity caused greater variation in the cumulative surface runoff, although its duration was only $38 \mathrm{~min}$. In longer durations associated with high Int, greater depths drained would possibly be observed in comparison to the other rainfalls applied, because surface runoff is directly related to rainfall intensity (Kinnell, 2016),

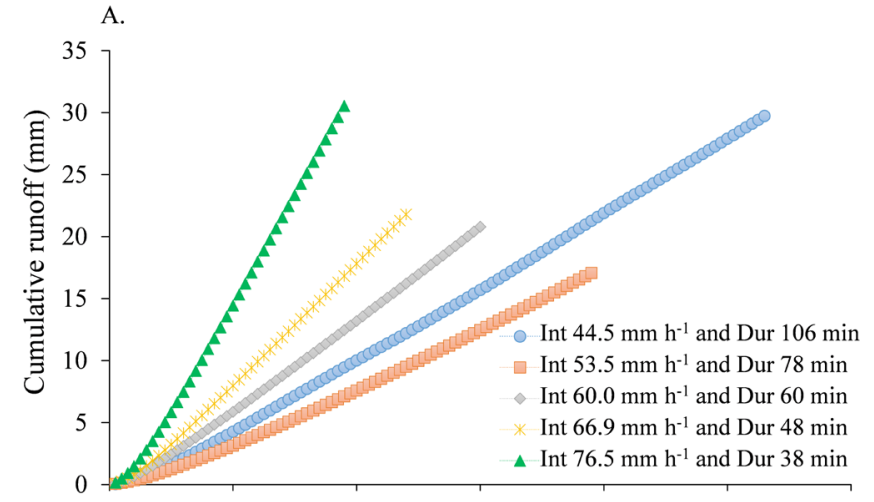

B.

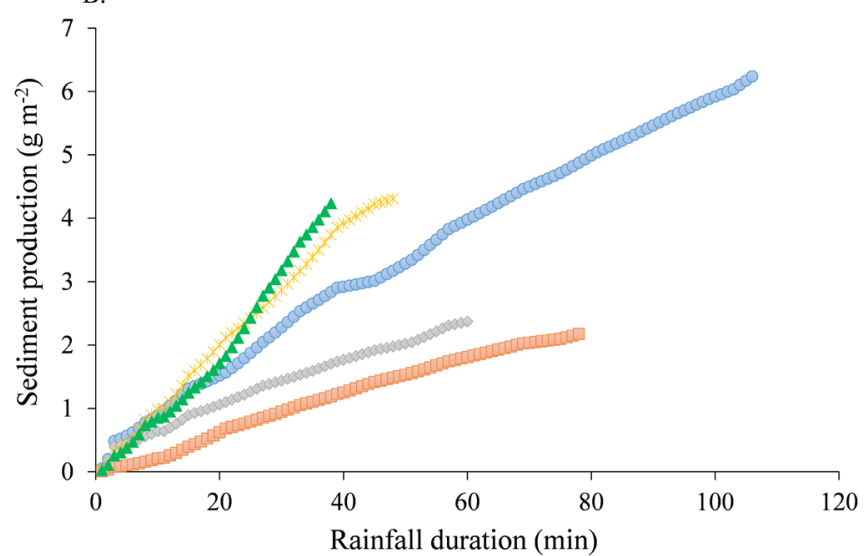

Figure 1. Cumulative surface runoff (A) and cumulative sediment production (B) as a function of rainfall duration after the beginning of surface runoff for the different treatments, in Ultisol

rainfall duration and precipitated depth, although this effect is not fully explained in some studies (Wang et al., 2017). Possibly, the variation in surface runoff depths results from the precipitated depth in the preestablished time, although differences between treatments were expected due to the different associations between rainfall duration and intensity. The effect of rainfall intensity on surface runoff is not direct, because the erodibility and terrain surface conditions interfere with this process (Ran et al., 2012; An et al., 2014; Wang et al., 2017).

The amount of sediments disaggregated and transported in all treatments increased with rainfall duration (from Int $76.5 \mathrm{~mm} \mathrm{~h}^{-1}$ and Dur $38 \mathrm{~min}$ to Int $44.5 \mathrm{~mm} \mathrm{~h}^{-1}$ and

Table 1. Total organic carbon $\left(\mathrm{C}_{\text {org }}\right.$ ), geometric diameter (GD), weight diameter (WD), macroporosity (Macro), microporosity (Micro), total porosity (TP), soil bulk density (BD) and soil moisture prior to the rainfalls (Moisture) in the $0-0.10 \mathrm{~m}$ layer of the experimental area

\begin{tabular}{|c|c|c|c|c|c|}
\hline \multirow[b]{2}{*}{ Soil attributes } & \multicolumn{5}{|c|}{ Treatments } \\
\hline & $\begin{array}{l}\text { Int } 44.5 \mathrm{~mm} \mathrm{~h}^{-1} \\
\text { and Dur } 106 \mathrm{~min}^{-}\end{array}$ & $\begin{array}{l}\text { Int } 53.5 \mathrm{~mm} \mathrm{~h}^{-1} \\
\text { and Dur } 78 \mathrm{~min}\end{array}$ & $\begin{array}{l}\text { Int } 60.0 \mathrm{~mm} \mathrm{~h}^{-1} \\
\text { and Dur } 60 \mathrm{~min}\end{array}$ & $\begin{array}{l}\text { Int } 66.9 \mathrm{~mm} \mathrm{~h}^{-1} \\
\text { and Dur } 48 \mathrm{~min}\end{array}$ & $\begin{array}{l}\text { Int } 76.5 \mathrm{~mm} \mathrm{~h}^{-1} \\
\text { and Dur } 38 \mathrm{~min}\end{array}$ \\
\hline $\mathrm{C}_{\text {org }}\left(\mathrm{g} \mathrm{kg}^{-1}\right)$ & $27.64 \mathrm{a}$ & $24.76 \mathrm{a}$ & $21.20 \mathrm{a}$ & $25.10 \mathrm{a}$ & $16.83 \mathrm{a}$ \\
\hline $\mathrm{GD}(\mathrm{mm})$ & $4.35 \mathrm{a}$ & $4.40 \mathrm{a}$ & $4.22 \mathrm{a}$ & $4.65 \mathrm{a}$ & $4.35 \mathrm{a}$ \\
\hline WD (mm) & $4.68 \mathrm{a}$ & $4.71 \mathrm{a}$ & $4.64 \mathrm{a}$ & $4.83 \mathrm{a}$ & $4.71 \mathrm{a}$ \\
\hline Macro (\%) & $15.61 \mathrm{a}$ & $16.32 \mathrm{a}$ & $17.05 \mathrm{a}$ & $15.46 \mathrm{a}$ & $12.90 \mathrm{a}$ \\
\hline Micro (\%) & $27.83 \mathrm{a}$ & $27.51 \mathrm{a}$ & $26.85 a$ & $27.35 \mathrm{a}$ & $28.36 \mathrm{a}$ \\
\hline $\mathrm{BD}\left(\mathrm{g} \mathrm{cm}^{-3}\right)$ & $1.01 \mathrm{a}$ & $0.97 \mathrm{a}$ & $0.95 \mathrm{a}$ & $0.97 \mathrm{a}$ & $0.96 \mathrm{a}$ \\
\hline Moisture $\left(\mathrm{cm}^{3} \mathrm{~cm}^{-3}\right)$ & $0.23 \mathrm{a}$ & $0.19 b$ & $0.18 b$ & $0.24 \mathrm{a}$ & $0.22 \mathrm{a}$ \\
\hline
\end{tabular}

Means followed by the same letters, for the same soil attribute, do not differ by Scott-Knott test at $\mathrm{p} \leq 0.05$; Int - Rainfall intensity; Dur - Rainfall duration; $\mathrm{C}_{\text {org }}$ - Organic carbon GD - Geometric diameter; WD - Weight diameter; Macro - Macroporosity; Micro - Microporosity; TP - Total porosity; BD - Bulk density 
Dur $106 \mathrm{~min}$ ) (Figure 1B). The largest sediment production was caused by the rainfall with Int $44.5 \mathrm{~mm} \mathrm{~h}^{-1}$ and Dur $106 \mathrm{~min}$. On the other hand, a less accentuated increment was observed in the simulated rainfall with Int $53.5 \mathrm{~mm} \mathrm{~h}^{-1}$ and Dur $78 \mathrm{~min}$, compared to the treatment with Int $44.5 \mathrm{~mm} \mathrm{~h}^{-1}$ and Dur $106 \mathrm{~min}$, consistent with lower surface runoff depth, which reduces sediment production. The effect of surface runoff on sediment production was verified and confirmed with the lowest values of sediment production observed in the same treatments with the lowest depths of surface runoff (Table 2). Regarding the time required for the surface runoff to begin, in the treatment with Int $53.5 \mathrm{~mm} \mathrm{~h}^{-1}$ and Dur 78 min was higher comparing with the other ones. Such difference occurred possibly because of the lower moisture prior to the rainfalls in this treatment (Table 1) and due to the roughness conditions of the terrain surface (Almeida et al., 2016; Zhao et al., 2018).

Soil losses varied from 2.17 to $6.12 \mathrm{~g} \mathrm{~m}^{-2}$, respectively in the treatments Int $53.5 \mathrm{~mm} \mathrm{~h}^{-1}$ and Dur $78 \mathrm{~min}$ and Int $44.5 \mathrm{~mm} \mathrm{~h}^{-1}$ and Dur $106 \mathrm{~min}$. Sediment production was equal in the treatments Int $53.5 \mathrm{~mm} \mathrm{~h}^{-1}$ and Dur $78 \mathrm{~min}$ and Int $60.0 \mathrm{~mm} \mathrm{~h}^{-1}$ and Dur $60 \mathrm{~min}$ and different from those observed in the other combinations of rainfalls applied, being equal between the rainfalls with Int $44.5 \mathrm{~mm} \mathrm{~h}^{-1}$ and Dur $106 \mathrm{~min}$ and Int $66.9 \mathrm{~mm} \mathrm{~h}^{-1}$ and Dur $48 \mathrm{~min}$ and Int $76.5 \mathrm{~mm} \mathrm{~h}^{-1}$ and Dur $38 \mathrm{~min}$.

In an experimental area close to the one of this study and with the same soil type, Carvalho et al. (2015) quantified average sediment production of $9.5 \mathrm{~g} \mathrm{~m}^{-2}$ from the application of rainfall with intensity of $60 \mathrm{~mm} \mathrm{~h}^{-1}$ and duration of $60 \mathrm{~min}$. In the present study, an average sediment production of $2.37 \mathrm{~g} \mathrm{~m}^{-2}$ was observed for the same type of rainfall (Int $60.0 \mathrm{~mm} \mathrm{~h}^{-1}$ and Dur $60 \mathrm{~min}$ ). The differences can be explained by factors such as organic carbon content, porosity and aggregate stability (Table 1), influenced by the time along which the area remained covered by grass. The carbon supplied to the soil by grass roots contributes to the formation of larger, more stable aggregates and also favors soil porosity by structuring the soil and through the physical effect of the roots, creating spaces for water infiltration. According to Almeida et al. (2016), greater water infiltration in the soil can be observed, which decreases the volume drained superficially.

In Cerrado area, Almeida et al. (2016) quantified average sediment production of $25.3 \mathrm{~g} \mathrm{~m}^{-2}$ in Ultisol, under rainfall of $60 \mathrm{~mm} \mathrm{~h}^{-1}$ with duration of $60 \mathrm{~min}$. These differences may be associated with the variability of soil physical properties, erodibility, terrain cover conditions and the characteristics of the rainfalls applied. The means of the replicates of a same type of rainfall may be different, with the respective variations in the amount of sediments produced by the same rainfall event, according to the attributes of the soil (He et al., 2017).

In this study it was observed that rainfalls with different combinations of duration and intensity and with similar erosivity have an effect on sediment production, although no differences were found in the surface runoff. Other authors have also reported similar results regarding surface runoff and sediment production under simulated rainfall (Ran et al., 2012; An et al., 2014; Wang et al., 2017).

For all treatments, the surface runoff rates stabilized after approximately $20 \mathrm{~min}$ of rainfall application, which has also been observed under laboratory conditions (He et al., 2017). In general, higher surface runoff rates are observed for rainfalls with higher intensity (Figure 2A).

As observed for surface runoff, the sediment production rates for all treatments are initially lower (Figure 2B). After around $20 \mathrm{~min}$, as the duration increases, sediment production rates decrease for all treatments, although not so expressively for Int $76.5 \mathrm{~mm} \mathrm{~h}^{-1}$ and Dur $38 \mathrm{~min}$, due to the short rainfall duration (38 $\mathrm{min}$ ) (Figure $2 \mathrm{~B}$ ). In general, the highest rates of sediment production and surface runoff are observed for rainfalls with the highest intensity, especially the treatments Int $66.9 \mathrm{~mm} \mathrm{~h}^{-1}$ and Dur $48 \mathrm{~min}$ and Int $76.5 \mathrm{~mm} \mathrm{~h}^{-1}$ and Dur $38 \mathrm{~min}$. Sediment production rates higher than the ones observed in the present study were found by Carvalho et al. (2015) for the same soil in an experimental area beside the area of the present study, after soil overturning.
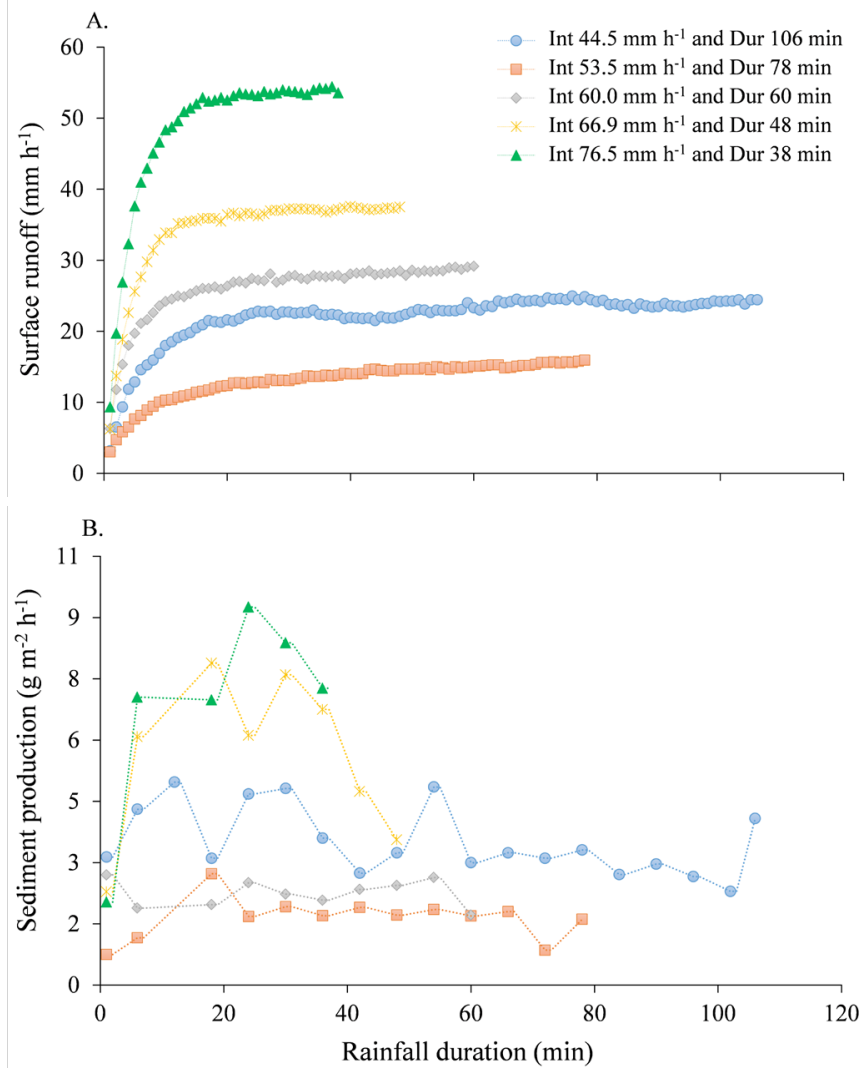

Figure 2. Rates of surface runoff (A) and sediment production (B) as a function of rainfall duration after the beginning of surface runoff for the different treatments, in Ultisol

Table 2. Surface runoff, cumulative sediment production and time for surface runoff for the different treatments, in an Ultisol

\begin{tabular}{|c|c|c|c|c|c|}
\hline \multirow[b]{2}{*}{ Variable } & \multicolumn{5}{|c|}{ Treatments } \\
\hline & $\begin{array}{l}\text { Int } 44.5 \mathrm{~mm} \mathrm{~h}^{-1} \\
\text { and Dur } 106 \mathrm{~min}\end{array}$ & $\begin{array}{l}\text { Int } 53.5 \mathrm{~mm} \mathrm{~h}^{-1} \\
\text { and Dur } 78 \mathrm{~min}\end{array}$ & $\begin{array}{l}\text { Int } 60.0 \mathrm{~mm} \mathrm{~h}^{-1} \\
\text { and Dur } 60 \mathrm{~min}\end{array}$ & $\begin{array}{l}\text { Int } 66.9 \mathrm{~mm} \mathrm{~h}^{-1} \\
\text { and Dur } 48 \mathrm{~min}\end{array}$ & $\begin{array}{l}\text { Int } 76.5 \mathrm{~mm} \mathrm{~h}^{-1} \\
\text { and Dur } 38 \mathrm{~min}\end{array}$ \\
\hline Runoff (mm) & $29.73 \mathrm{a}$ & $17.07 \mathrm{a}$ & $20.79 a$ & $21.79 \mathrm{a}$ & $30.53 \mathrm{a}$ \\
\hline Sediments ( $\left.\mathrm{g} \mathrm{m}^{-2}\right)$ & $6.12 \mathrm{a}$ & $2.17 b$ & $2.37 \mathrm{~b}$ & $4.30 \mathrm{a}$ & $4.23 \mathrm{a}$ \\
\hline Time for runoff (min) & $9.87 \mathrm{~b}$ & $22.50 \mathrm{a}$ & $10.75 b$ & $10.50 \mathrm{~b}$ & $8.60 \mathrm{~b}$ \\
\hline
\end{tabular}

Means followed by the same letters in the row do not differ by Scott-Knott at $\mathrm{p} \leq 0.05$; Int - Rainfall intensity; Dur - Rainfall duration 
Usually, the concentration of sediments in the flood is directly related to rainfall intensity and, therefore, it is indispensable to quantify surface runoff rates during the application of rainfall events for better understanding of the soil erosive process (Kinnell, 2016). The ratio between sediment production and surface runoff varies similarly between the different rainfall combinations applied (Figure 3). The ratio is initially high, when the surface runoff is lower. As rainfall duration increases, the runoff increases because the inlet of rainwater is constant. As a consequence, the ratio between sediment production and surface runoff decreases. From $20 \mathrm{~min}$ after the runoff, the sediment/runoff ratio is virtually constant in each type of rainfall (Figure 3).

The sediment/runoff ratio is higher in the treatment Int $44.5 \mathrm{~mm} \mathrm{~h}^{-1}$ and Dur $106 \mathrm{~min}$ along the entire period of rainfall application, with maximum value close to $2.0 \mathrm{~g} \mathrm{~m}^{-2} \mathrm{~mm}^{-1}$ (Figure 3). The other ratios were initially higher in the treatments Int $60.0 \mathrm{~mm} \mathrm{~h}^{-1}$ and Dur $60 \mathrm{~min}$, Int $66.9 \mathrm{~mm} \mathrm{~h}^{-1}$ and Dur $48 \mathrm{~min}$, Int $53.5 \mathrm{~mm} \mathrm{~h}^{-1}$ and Dur $78 \mathrm{~min}$, and Int $76.5 \mathrm{~mm} \mathrm{~h}^{-1}$ and Dur $38 \mathrm{~min}$. From $20 \mathrm{~min}$, there is an alteration in this order of higher sediment/runoff ratio, which is possibly related to the intensity of the rainfalls. For the highest intensities, if associated with longer duration, a higher sediment/runoff ratio could be observed, because rainfall intensity and duration increased the sediment production rates, and some studies have reported linear relationship between the depth drained superficially and sediment production (Mathys et al., 2005; Pan \& Shangguan, 2006; Bertol et al., 2017).

The variation of soil water infiltration is similar for the different conditions of simulated rainfall. After the beginning of surface runoff, soil water infiltration decreases rapidly, especially in the initial $10 \mathrm{~min}$ (Figure 4). Stable infiltration rate (SIR) of the treatment with Int $53.5 \mathrm{~mm} \mathrm{~h}^{-1}$ and Dur $78 \mathrm{~min}$ is approximately two times greater than the lowest SIR, quantified in the treatment with Int $44.5 \mathrm{~mm} \mathrm{~h}^{-1}$ and Dur 106 min.

The mean values of SIR in the treatments were 21.6, 37.7, 31.4, 29.5 and $22.4 \mathrm{~mm} \mathrm{~h}^{-1}$, respectively, for Int $44.5 \mathrm{~mm} \mathrm{~h}^{-1}$ and Dur $106 \mathrm{~min}$; Int $53.5 \mathrm{~mm} \mathrm{~h}^{-1}$ and Dur $78 \mathrm{~min}$; Int $60.0 \mathrm{~mm} \mathrm{~h}^{-1}$ and Dur $60 \mathrm{~min}$; Int $66.9 \mathrm{~mm} \mathrm{~h}^{-1}$ and Dur $48 \mathrm{~min}$; and Int $76.5 \mathrm{~mm} \mathrm{~h}^{-1}$ and Dur $38 \mathrm{~min}$ (Figure 4), with no significant difference between the different combinations of rainfall applied (Skott-Knott, at $\mathrm{p} \leq 0.05)$.

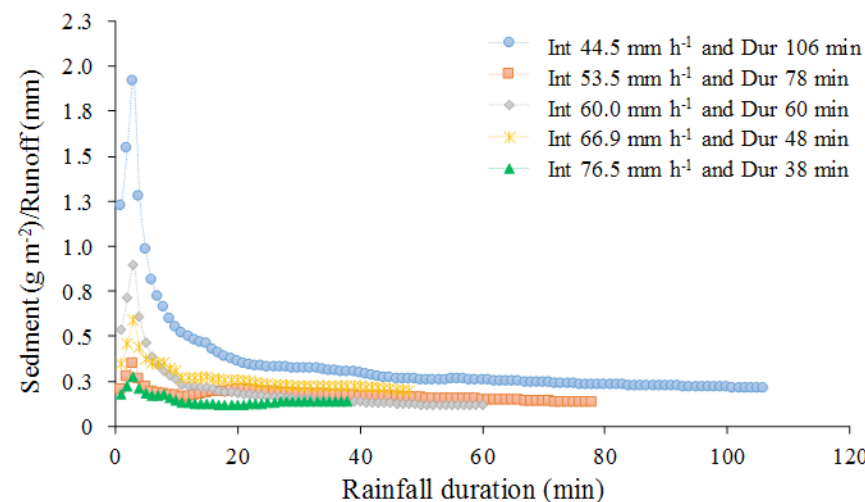

Figure 3. Ratio between sediment production and surface runoff as a function of rainfall duration after the beginning of surface runoff for the different treatments, in Ultisol

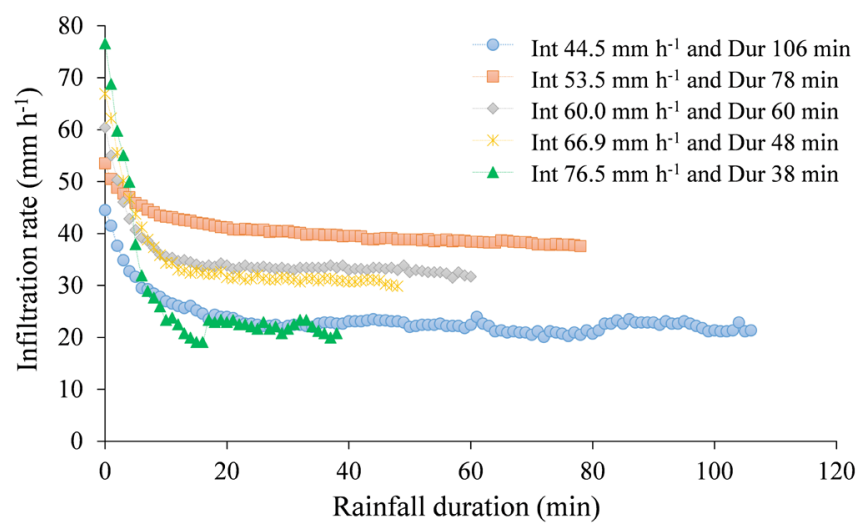

Figure 4. Soil water infiltration rate as a function of rainfall duration after the beginning of surface runoff for the different treatments in Ultisol

Soils with medium and/or clayey texture and without vegetation cover on surface may have their infiltration capacity reduced, leading to higher surface runoff and lower water infiltration rates (Cerdà, 1999; Almeida et al., 2018; Zhao et al., 2018). It is observed in this study, that the infiltration rate of the soil gradually decreases with the increment in cumulative rainfall. Zhao et al. (2018) claim that, once the infiltration rate is lower than rainfall intensity, the excess of the precipitated depth contributes to the storage of water in the superficial depressions and, consequently, the runoff increases.

The characteristics intensity, duration and water depth applied in each rainfall, associated with the antecedent moisture content in soil and its physical-hydraulic properties control the phenomenon of infiltration. Therefore, higher rainfall intensities lead to a high frequency of impact of water droplets on soil, which alters the disaggregation of the particles, possibly causing superficial sealing and, consequently, decrease of water infiltration in soil and increase of surface runoff volume (Kinnell, 2016).

Values of steady-state infiltration rate have also been quantified in other studies under simulated rainfall and constant intensity. Evaluating water infiltration in soil under rainfall with intensity of $60 \mathrm{~mm} \mathrm{~h}^{-1}$ and duration of $60 \mathrm{~min}$, Almeida et al. (2018) found low SIR $\left(2.1 \mathrm{~mm} \mathrm{~h}^{-1}\right)$ in Ultisol with sandy texture in a Cerrado area without vegetation cover, after soil overturning and six rainfall applications (120 days after soybean sowning). The low SIR was mainly related to the formation of superficial sealing and accommodation of soil particles, which reduced total porosity and macroporosity, since the overturning breaks soil aggregates and destroys its structure. Superficial sealing and lower porosity increase the water volume drained superficially due to the clogging of soil pores and, consequently, infiltration is reduced. Carvalho et al. (2015) quantified SIR of $11.6 \mathrm{~mm} \mathrm{~h}^{-1}$ in an area beside the one of the present study, after four applications of rainfall in soil with no vegetation cover ( 75 days after overturning). Such difference is related to the soil attributes which influence water infiltration, to soil tillage, vegetation cover on surface, porosity, bulk density, organic carbon content, size and stability of soil aggregates, and the soil moisture prior to the application of rainfalls. Usually, soil overturning is used to increase soil porosity. However, such effect on porosity is temporary and 
decreases rapidly (Carvalho et al., 2015; Almeida et al., 2016, 2018). Thus, in areas with overturned soil and no vegetation cover on the surface, the volume drained superficially increases and water infiltration decreases.

\section{Conclusion}

Rainfalls with similar erosivity and different combinations of duration and intensity alter the process of sediment production, but do not influence soil water infiltration and surface runoff.

\section{ACKNOWLedgments}

The authors thank the Universidade Federal Rural do Rio de Janeiro - UFRRJ, the Coordenação de Aperfeiçoamento de Pessoal de Nível Superior - (CAPES, Brazil), the Conselho Nacional de Desenvolvimento Científico e Tecnológico (CNPq, Brazil) and the Agência da Bacia do Rio Paraíba do Sul - AGEVAP, Comitê da Bacia do Rio Guandu, for the financial support.

\section{Literature Cited}

Almeida, W. S. de; Carvalho, D. F. de; Panachuki, E.; Valim, W. C.; Rodrigues, S. A.; Varella, C. A. A. Erosão hídrica em diferentes sistemas de cultivo e níveis de cobertura do solo. Pesquisa Agropecuária Brasileira, v.51, p.1110-1119, 2016. https://doi. org/10.1590/s0100-204x2016000900010

Almeida, W. S. de; Panachuki, E.; Oliveira, P. T. S. de; Menezes, R. da S.; Alves Sobrinho, T.; Carvalho, D. F. de. Effect of soil tillage and vegetal cover on soil water infiltration. Soil \& Tillage Research, v.175, p.130-138, 2018. https://doi.org/10.1016/j.still.2017.07.009

Alvares, C. A.; Stape, J. L.; Sentelhas, P. C.; Gonçalves, J. L. de M.; Sparovek, G. Köppen's climate classification map for Brazil. Meteorologische Zeitschrift, v.22, p.711-728, 2013. https:/doi. org/10.1127/0941-2948/2013/0507

Alves Sobrinho, T.; Carvalho, D. F. de; Aquino, R. M. de; Montebeller, C. A. Programa computacional para a definição de parâmetros hidráulicos utilizados na determinação da energia cinética da chuva simulada em infiltrômetro de aspersão. Engenharia Rural, v.12, p.15-19, 2001. https://doi.org/10.1111/j.14752743.2008.00150.x

Alves Sobrinho, T.; Macpherson, H. G.; Gómez, J. A. A portable integrated rainfall and overland flow simulator. Soil Use and Management, v.24, p.163-170, 2008.

An, J.; Zheng, F. L.; Han, Y. Effects of rainstorm patterns on runoff and sediment yield processes. Soil Science, v.179, 293-303, 2014. https://doi.org/10.1097/SS.0000000000000068

Bako, A. N.; Darboux, F.; James, F.; Josserand, C.; Lucas, C. Pressure and shear stress caused by raindrop impact at the soil surface: Scaling laws depending on the water depth. Earth Surface Processes and Landforms, v.41, p.1199-1210, 2016. https://doi. org/10.1002/esp.3894

Bartlett, M. S. Properties of sufficiency and statistical tests. Proceedings of the Royal Society A, v.160, p.268-282, 1937. https:// doi.org/10.1098/rspa.1937.0109
Bertol, I.; Schick, J.; Bandeira, D. H.; Paz-Ferreiro, J.; Vázquez, E. V. Multifractal and joint multifractal analysis of water and soil losses from erosion plots: A case study under subtropical conditions in Santa Catarina highlands, Brazil. Geoderma, v.287, p.116-125, 2017. https://doi.org/10.1016/j.geoderma.2016.08.008

Borrelli, P.; Robinson, D. A.; Fleischer, L. R.; Lugato, E.; Ballabio, C.; Alewell, C.; Meusburger, K.; Modugno, S.; Schütt, B.; Ferro, V.; Bagarello, V.; Oost, K. van; Montanarella, L.; Panagos, P. An assessment of the global impact of $21^{\text {st }}$ century land use change on soil erosion. Nature Communications, v.8, p.1-13, 2013. https:// doi.org/10.1038/s41467-017-02142-7

Carvalho, D. F. de; Eduardo, E. N.; Almeida, W. S. de; Santos, L. A. F. dos; Alves Sobrinho, T. Water erosion and soil water infiltration in different stages of corn development and tillage systems. Revista Brasileira de Engenharia Agrícola e Ambiental, v.19, p.1072-1078, 2015. https://doi.org/10.1590/1807-1929/agriambi. v19n11p1072-1078

Cerdà, A. Seasonal and spatial variations in infiltration rates in badland surfaces under Mediterranean climatic conditions. Water Resources Research, v.35, p.319-328, 1999. https://doi. org/10.1029/98WR01659

Cruz, E. S. da. Influência do preparo do solo e de plantas de cobertura na erosão hídrica de um Argissolo Vermelho-Amarelo. Seropédica: Universidade Federal Rural do Rio de Janeiro, 2006. 69p. Dissertação Mestrado

He, J.-J.; Sun, L.-Y.; Gong, H.-L.; Cai, Q.-G. Laboratory studies on the influence of rainfall pattern on rill erosion and its runoff and sediment characteristics. Land Degradation \& Development, v.28, p.1615-1625, 2017. https://doi.org/10.1002/ldr.2691

Kinnell, P. I. A. A review of the design and operation of runoff and soil loss plots. Catena, v.145, p.257-265, 2016. https://doi. org/10.1016/j.catena.2016.06.013

Mathys, N.; Klotz, S.; Esteves, M.; Descroix, L.; Lapetite, J. M. Runoff and erosion in the Black Marls of the French Alps: Observations and measurements at the plot scale. Catena, v.63, p.261-281, 2005. https://doi.org/10.1016/j.catena.2005.06.010

Pan, C.; Shangguan, Z. Runoff hydraulic characteristics and sediment generation in sloped grassplots under simulated rainfall conditions. Journal of Hydrology, v.331, p.178-185, 2006. https:// doi.org/10.1016/j.jhydrol.2006.05.011

Panagos, P.; Borrelli, P.; Meusburger, K.; Yu, B.; Klik, A.; Lim, K. J.; Yang, J. E.; Ni, J.; Miao, C.; Chattopadhyay, N.; Sadeghi, S. H.; Hazbavi, Z.; Zabihi, M.; Larionov, G. A.; Krasnov, S. F.; Gorobets, A. V.; Levi, Y.; Erpul, G.; Birkel, C.; Hoyos, N.; Naipal, V.; Oliveira, P. T. S.; Bonilla, C. A.; Meddi, M.; Nel, W.; Dashti, H. A.; Bonil, M.; Diodato, N.; Oost, K. van; Nearing, M.; Ballabio, C. Global rainfall erosivity assessment based on high-temporal resolution rainfall records. Scientific Reports, v.7, p.1-12, 2017. https://doi. org/10.1038/s41598-017-04282-8

Ran, Q.; Su, D.; Li, P.; He, Z. Experimental study of the impact of rainfall characteristics on runoff generation and soil erosion. Journal of Hydrology, v.424, p.99-111, 2012. https://doi. org/10.1016/j.jhydrol.2011.12.035

Santos, H. G. dos; Jacomine, P. K. T.; Anjos, L. H. C. dos; Oliveira, V. A. de; Lumbreras, J. F.; Coelho, M. R.; Almeida, J. A. de; Araújo Filho, J. C. de; Oliveira, J. B. de; Cunha, T. J. F. Sistema brasileiro de classificação de solos. 5.ed. Brasília: Embrapa Informação Tecnológica, 2018. 590p. 
Shapiro, S. S.; Wilk, M. B. An analysis of variance test for normality (complete samples). Biometrika, v.52, p.591-611, 1965. https:// doi.org/10.1093/biomet/52.3-4.591

Teixeira, P. C.; Donagemma, G. K.; Fontana, A.; Teixeira, W. G. (eds.). Manual de métodos de análise de solo. 3.ed. rev. ampl. Brasília: Embrapa Informação Tecnológica, 2017. 573p.

Wang, B.; Steiner, J.; Zheng, F.; Gowda, P. Impact of rainfall pattern on interrill erosion process. Earth Surface Processes and Landforms, v.42, p.1833-1846, 2017. https://doi.org/10.1002/esp.4140

Wang, X.; Zhao, X.; Zhang, Z.; Yi, L.; Zuo, L.; Wen, Q.; Liu, F.; Xu, J.; Hu, S.; Liu, B. Assessment of soil erosion change and its relationships with land use/cover change in China from the end of the 1980s to 2010. Catena, v.137, p.256-268, 2016. https://doi. org/10.1016/j.catena.2015.10.004

Wischmeier, W. H.; Smith, D. D. Predicting rainfall erosion losses: A guide to conservation planning. Washington: USDA, 1978. 58p. Agricultural Handbook, 537
Wu, X.; Wei, Y.; Wang, J.; Cai, C.; Deng, Y.; Xia, J. RUSLE erodibility of heavy textured soils as affected by soil type, erosional degradation, and rainfall intensity: A field simulation. Land Degradation \& Development, v.29, p.408-421, 2018a. https://doi.org/10.1002/ ldr.2864

Wu, X.; Wei, Y.; Wang, J.; Xia, J.; Cai, C.; Wei, Z. Effects of soil type and rainfall intensity on sheet erosion processes and sediment characteristics along the climatic gradient in central-south China. Science of the Total Environment, v.621, p.54-66, 2018b. https:// doi.org/10.1016/j.scitotenv.2017.11.202

Zhang, X. C.; Wang, Z. L. Interrill soil erosion processes on steep slopes. Journal of Hydrology, v.548, p.652-664, 2017. https://doi. org/10.1016/j.jhydrol.2017.03.046

Zhao, L.; Hou, R.; Wu, F.; Keesstra, S. Effect of soil surface roughness on infiltration water, ponding and runoff on tilled soils under rainfall simulation experiments. Soil \& Tillage Research, v.179, p.47-53, 2018. https://doi.org/10.1016/j.still.2018.01.009 